\title{
Potential and constraints for applying the "4 per 1000 Initiative" in the Caribbean: the case of Guadeloupe
}

\author{
Pierre Chopin $^{1,2} \cdot$ Jorge Sierra ${ }^{2}$ \\ Received: 27 July 2020 / Accepted: 16 November 2020 \\ (C) The Author(s) 2021
}

\begin{abstract}
This paper assesses the feasibility of the 4 per 1000 initiative for agricultural soils in the tropics more specifically in Guadeloupe, as a representative case study of the Caribbean and other tropical regions. We used a locally adapted and calibrated model describing soil organic carbon dynamics under the impact of climate change and a broad range of scenarios combining increased use of organic amendments, reduced soil tillage, and increased land area for the local market. We found that, in its current state, only $26 \%$ of agricultural area could achieve a $4 \%$ year $^{-1}$ increase in soil organic carbon (SOC) stocks in the coming 30 years, due mainly to perennial cropping systems (sugarcane, banana, orchards) occupying soils with the lowest SOC stocks. Implementing reduced tillage with increased use of locally produced composts would increase the agricultural area reaching the 4 per 1000 target to $31 \%$. However, at territory scale, all scenarios tested showed an annual decrease in SOC stocks varying from -0.1 to $3.2 \%$. The limited area on which the 4 per 1000 target is feasible and generalized SOC losses were mainly linked to the current high SOC stocks in volcanic and calcareous soils on the island and lack of practices capable of further increasing $\mathrm{C}$ inputs in current cropping systems. We concluded that $\mathrm{C}$ sequestration potential in the Caribbean is rather limited and that increasing SOC stocks, even lower than 4 per 1000, should be the primary target in adaptation to climate change, by increasing the resilience of cropping systems based mainly on SOC-poor soils.
\end{abstract}

Keywords Climate change mitigation $\cdot$ Compost use $\cdot$ Cropping system $\cdot \mathrm{C}$ sequestration $\cdot$ Land use change $\cdot$ Reduced tillage

\section{Introduction}

The "4 per 1000 Initiative: Soils for Food Security and Climate" proposed at the United Nations Climate Change

Communicated by Cornelia Rumpel and accepted by Topical Collection Chief Editor Christopher Reyer

This article is part of the Topical Collection on Regional management practices with positive effects on soil carbon to meet the goals of the 4 p1000 initiative

Pierre Chopin

pierre.chopin@slu.se

Jorge Sierra

jorge.sierra@inrae.fr

1 Department of Crop Production Ecology, Swedish University of Agricultural Sciences, Ekologicentrum, Ulls väg,

75651 Uppsala, Sweden

2 INRAE, UR ASTRO, Domaine Duclos, Prise D'Eau, 97176, F-97170 Petit-Bourg, Guadeloupe, France
Conference (COP21) in Paris in 2015 aims at increasing global soil organic carbon (SOC) stocks by 4 per 1000 (or $0.4 \%$ ) per year to compensate for global anthropogenic emissions of fossil C (Soussana et al. 2019). This initiative acknowledges the key role of soils in addressing the three-fold challenge of food security, adaptation to climate change, and mitigation of human-induced greenhouse gas (GHG) emissions (Minasny et al. 2018; Lal 2020). Although several methods of calculation of the 4 per 1000 and various interpretations of this figure have been proposed in the literature (Minasny et al. 2018, for a detailed discussion on this topic), there is currently a consensus concerning the fact that the 4 per 1000 is not a normative target value for each country or region, but is intended to show that even a small SOC increase is crucial to improve soil quality and contribute to climate change mitigation and adaptation (4 per 1000 Initiative 2020; Rumpel et al. 2020).

Adoption of improved agronomic practices in temperate and tropical cropping systems often results in relative annual SOC increases that are at or above $4 \%$, mainly in soils with relatively low SOC stocks (Soussana et al. 2019). In a synthesis of internationally distributed, long-term field crop trials, 
Minasny et al. (2017) found that the relative increase in SOC stocks following adoption of good farming practices is usually higher when these practices are applied on degraded soils (e.g., on average 15\%o per year for an initial SOC stock of $20 \mathrm{Mg} \mathrm{C}^{-1}$ to $0.3 \mathrm{~m}$ or $0.4 \mathrm{~m}$ soil depth) than on SOC-rich soils (e.g., $4 \%$ o per year for an initial SOC stock of $80 \mathrm{Mg} \mathrm{C}$ $\mathrm{ha}^{-1}$ ). In tropical regions, soil degradation and high SOC losses are serious issues, linked to the hot climate, resourcepoor smallholder farming, and widespread extractive soil management (Lal 2019). Suggested farming practices to overcome these issues include retention of crop residues, use of cover crops and organic amendments, use of crop rotations, and reduced soil disturbance (Lal 2019). In a literature review on SOC storage in soils in sub-Saharan Africa, Corbeels et al. (2019) reported SOC increases $>4 \%$ year $^{-1}$ when no-till or minimum tillage, crop residue retention, and intercropping or rotation were applied simultaneously. They concluded that, although there is high potential for application of the " 4 per 1000 Initiative" in tropical degraded soils, low SOC levels are largely the result of the limited resources available to most smallholder farmers in these regions (Corbeels et al. 2019).

There are currently limited published data on application of the "4 per 1000 Initiative" to tropical soils, and to our knowledge, no study has carried out on this topic for Caribbean soils. It is well known that the residence time of SOC in tropical soils is much shorter than in temperate soils. Moreover, as pointed out by Milne et al. (2016), modeling studies on SOC dynamics in the tropics can provide future valuable information for colder regions under climate change. As in other tropical regions, SOC turnover in Caribbean soils is fast and can promote high SOC losses, which could be exacerbated by climate change (Chopin and Sierra 2019). However, as most Caribbean soils originate from volcanic ash or coral reefs, they contain relatively high SOC stocks, a situation favored by the presence of aluminum and iron hydrous oxides, allophanic materials, and smectite clay characterized by high SOC retention (Colmet-Daage and Lagache 1965). Consequently, SOC stocks in the top $0.3 \mathrm{~m}$ of Caribbean soils are generally 2-3 times greater than those in other tropical soils (e.g., Akpa et al. 2016; Corbeels et al. 2019). On the other hand, Caribbean agriculture is undergoing a shift in production towards domestic markets, which includes a transition towards cropping systems based on annual crops (e.g., annual vegetables, tuber crops, and root crops), because of declining demand on global markets for the major agricultural exports from the region (e.g., sugar, bananas, cocoa) (Saint Ville et al. 2015). As a consequence of this, Caribbean agriculture displays a large range of cropping systems involving contrasting farming practices and with very different impacts on SOC stocks: from perennial systems characterized by positive or neutral effects on SOC change to annual crops with slight or severe SOC losses (Sierra et al. 2015). This makes this region an interesting case when analyzing the potential and constraints for applying the "4 per 1000 Initiative" worldwide, especially under tropical conditions.

The present study was performed in the Guadeloupe archipelago, which contains, within a small area, nearly every physical landscape and cropping system found in the Caribbean. The objectives of the study were (i) to assess the land area where the " 4 per 1000 Initiative" could be achieved under the current soil management, and (ii) to test the impact of a change in farming practices on that land area, in order to assess whether the 4 per 1000 is feasible at local level and under what conditions. The analysis focused on the effects of diversity in soils and crops (initial SOC stocks, characteristics of cropping systems, and agro-ecological regions) and in farming practices (use of organic amendments and intensity of soil tillage). The land area potentially involved in the " 4 per 1000 Initiative" was estimated using the MorGwanik model of SOC dynamics, which has already been calibrated and tested for the conditions in Caribbean agriculture (Sierra et al. 2015).

\section{Materials and methods}

\section{Study site and agro-ecological characteristics}

The study was carried out on Guadeloupe, an archipelago in the eastern Caribbean with an overall cultivated area of 31 500 ha (Fig. 1). As proposed by Sierra et al. (2015), we divided the territory into five agro-ecological regions (AER), which represent homogeneous areas in terms of pedoclimatic conditions. Soils in AER 1 are Calcic Vertisols (FAO classification), with current SOC stocks of $60-75 \mathrm{Mg} \mathrm{C} \mathrm{ha}^{-1}(0-0.25 \mathrm{~m}$ soil layer) and characterized by high clay content (around $80 \%$ ) dominated by smectite. Soils in AER 2 are Acid Ferralsols, with SOC stocks ranging from 50 to $65 \mathrm{Mg} \mathrm{C} \mathrm{ha}^{-1}$ and a clay content of around $70 \%$ dominated by kaolinite. Cropping in AER 1 and AER 2 is dominated by sugarcane cultivation and grasslands, with a low proportion of vegetables and tuber crops (Table A1 in Appendix A of the Supplementary Material file). Soils in AER 3 are Andosols, with the highest SOC stocks in the territory $\left(90-110 \mathrm{Mg} \mathrm{C} \mathrm{ha}^{-1}\right)$ and a clay content of around $75 \%$ dominated by allophanes. Soils in AER 4 are Acid Nitisols, with SOC stocks ranging from 40 to $55 \mathrm{Mg} \mathrm{C} \mathrm{ha}{ }^{-1}$ and a clay content of around $70 \%$ dominated by halloysite. Banana and vegetables are the main crops in AER 3 and AER 4. Soils in AER 5 are Vertisols, with SOC stocks varying between 45 and $55 \mathrm{Mg} \mathrm{C}$ ha $^{-1}$ and a clay fraction of around $70 \%$ represented mainly by smectites and halloysite. Orchards (mainly citrus) and, to a lesser extent, vegetables are the main crops in AER 5. Information on land area, air temperature, and rainfall in each AER is presented in Fig. 1 and additional information is available in Table A1. Many organic amendments are 
Fig. 1 The Guadeloupe archipelago and its five agroecological regions (AER). Soils are Vertisols in AER 1 and AER 5, Ferralsols in AER 2, Andosols in AER 3, and Nitisols in AER 4. SOC contents correspond to the $0-0.25 \mathrm{~m}$ soil layer and represent the mean \pm standard deviation values reported by Sierra et al. (2015). The temperature and precipitation are mean annual values over the 1960-2015 period. AER 1 encompasses both GrandeTerre and Marie-Galante islands that have similar soil type and climatic conditions, and represent together 20600 ha

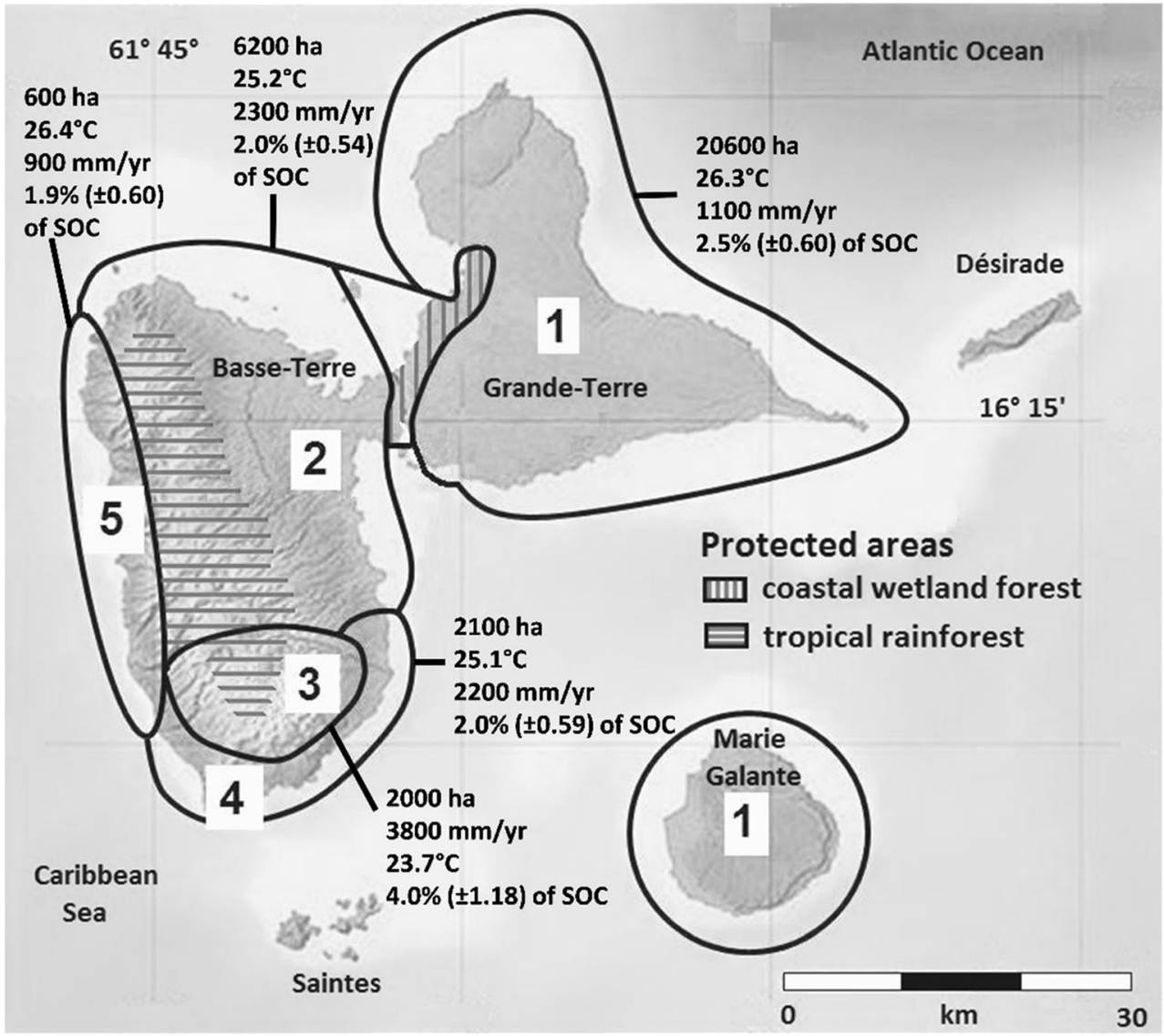

applied by farmers (e.g., manure, sugar scum, sewage sludge, vinasse, and compost), with the application rate varying widely between cropping systems and AERs (Table A2). As proposed by Chopin and Sierra (2019), in the present study, all organic amendments were expressed as equivalent compost, using the application rate of each amendment and the amount of humified soil $\mathrm{C}$ derived from the amendments compared with that from compost.

It is important to note that the whole grassland area included natural savannah devoted to livestock production for the local market, a system adopted by risk-adverse farmers devoting a very low level of resources to their farms. This land area was excluded from our analysis because few data on SOC stocks and dynamics are currently available for natural grasslands and the rate of conversion from grassland to cropland is negligible. Moreover, as these systems have a long occupation history ( $>100$ year) without changes in the grassland community and in land management, the soils may be considered near or at the equilibrium state for SOC stocks (Sierra et al. 2015).

\section{Model of soil organic carbon dynamics}

We used the MorGwanik model to simulate SOC dynamics. This model has been calibrated, tested, and validated for the soils, climates, and cropping systems in the Caribbean, and has been successfully applied to assess SOC dynamics at cropping system scale for all crops and associated farming practices in the different AERs of Guadeloupe (Sierra et al. 2015, 2017). The MorGwanik model simulates SOC change at plot scale as a function of $\mathrm{C}$ inputs and outputs, which can then be upscaled to assess the overall response of SOC change at AER and territory level.

Carbon inputs comprise crop residues (aboveground and roots) (Table A3) and organic amendments (Table A4). Carbon inputs from crop residues are calculated from the crop yield, the residues biomass/yield ratio, the $\mathrm{C}$ content of residues, and its coefficient of humification. Carbon inputs from organic amendments (expressed as equivalent compost) are calculated from the applied rate, the $\mathrm{C}$ content of the amendments, and their coefficient of humification. Carbon outputs are calculated using two coefficients which affect the SOC stock: the mineralization rate constant $k_{\mathrm{AER}}$ (Table A5), which is specific to each AER and reflects the impact of soil type and climate on SOC mineralization, and $k_{\text {crop }}$ (Table A3) which affects $k_{\mathrm{AER}}$ and is determined by the frequency and intensity of soil tillage (i.e., lower for perennial crops than for annual crops). Hence, $k_{\mathrm{AER}}$ value varies between AERs depending on their pedoclimatic conditions from $4.58 \times 10^{-2}$ in AER 2 to $2.50 \times 10^{-2}$ in AER 5, which shows that SOC nearly mineralize twice quicker in AER 2 than AER 5. 
The SOC stocks are calculated from data of current SOC contents (Table A6) and bulk density (Table A5) of each AER reported by Sierra et al. (2015). The values of SOC content are split in 3 or 4 SOC classes, and the middle value of these classes is used to calculate the SOC stock of each SOC class; i.e., $1.5 \%, 2.5 \%$, and $3.5 \%$ for AERs $1,2,4$, and 5 , and $2.5 \%$, $3.5 \%, 4.5 \%$, and $5.5 \%$ for AER3. This SOC stock is used in simulations to set the initial situation. The fraction of the land area corresponding to each SOC class in each AER is used to calculate the pooled SOC change at the AER level. Simulations were performed accounting for the impact of climate change on $\mathrm{C}$ inputs and outputs, as proposed by Chopin and Sierra (2019). For this, we used the climate change scenario elaborated by Météo France for the Guadeloupe archipelago, which is based on the A1B IPCC-SRES climate emissions scenario in the twenty-first century. It assumes an increase in temperature of about $0.02{ }^{\circ} \mathrm{C}$ year $^{-1}$ for the 30 -year simulation period (20152045) analyzed in this study (Brisson and Levrault 2011). Climate change affects simultaneously the $k_{\mathrm{AER}}$ coefficient and the amount of crop residues.

The model includes five databases which are used as model inputs: (i) land use in each AER (area occupied by each cropping system), (ii) soils in each AER ( $k_{\mathrm{AER}}$, bulk density and SOC classes), (iii) crops (yield, residues/yield ratio, C content, and coefficient of humification of crop residues), (iv) farming practices (characteristics of rotations and soil tillage for each system, type and rate of organic amendments, management of crop residues), and (v) climate change (change in air temperature in each AER). The values of model parameters used in simulations were those reported by Chopin and Sierra (2019).

\section{Scenarios of changes in farming practices and simulations}

The scenarios were built by changing three of the input parameters:

(1) Land use: The land use considered was either (i) the current distribution of crops or (ii) a $50 \%$ increase in the area occupied by annual crops devoted to the local market (i.e., $50 \%$ reduction in the area occupied by export crops such as sugarcane and banana).

(2) Amended area: The amended area considered was either (i) the current area fertilized with organic amendments or (ii) a $50 \%$ increase of the area with amendment.

(3) Soil tillage: Two levels of soil tillage are possible: (i) the current conventional tillage which is deep ploughing and (ii) a reduced tillage applied to annual crops grown for the local market. Conventional tillage is currently applied in all cropping systems in Guadeloupe and reduced tillage would provide an alternative to reduce SOC mineralization. The procedure used to assess the impact of reduced tillage was that proposed by Chopin and Sierra (2019).

In total, we tested eight scenarios of changes in farming practices, including two levels (current and modified) for each of the three parameters analyzed. The reference scenario (business-as-usual) was the current situation without any change in the parameters analyzed. These scenarios represent the present trend in Caribbean agriculture and well-accepted farming practices. The eight scenarios are summarized in Table A7.

As proposed by Eggleston et al. (2006), SOC changes were calculated for a 30-year period, 2015-2045. As described above, the model was initiated with SOC data reported by Sierra et al. (2015) corresponding to the year 2015. The land area on which the 4 per 1000 target can be attained (hereafter "4 per 1000 land area") was calculated based on the rate of SOC change, expressed in relation to the initial SOC stock $(\% 0$ year $^{-1}$ ) and calculated as:

Rate of SOC change

$$
=\left\{\left[\left(\mathrm{SOC}_{2045}-\mathrm{SOC}_{2015}\right) / 30\right] / \mathrm{SOC}_{2015}\right\} \times 1000
$$

where $\mathrm{SOC}_{2045}$ and $\mathrm{SOC}_{2015}$ are the SOC stocks in 2045 and 2015, respectively.

Simulations for a given cropping system $(n=4$ to 6 , Table A1) $\times$ AER $(n=5) \times$ scenario $(n=8$, Table A7) were performed for each class of SOC content $(n=3$ or 4 , Table A6) and each level of organic amendment use ( $n=2$; i.e., with and without). In total, 1264 simulations were carried out to estimate the 4 per 1000 land area. This included areas where the rate of SOC change was $\geq 4 \%$ o year $^{-1}$ at system, AER, and territory level. Differences in the effects of cropping systems, AERs, and the scenarios of land use on SOC changes were assessed by ANOVA under a factorial design using the XLSTAT ${ }^{\text {TM }} 2018.5$ program.

\section{Results}

\section{Factors affecting land area achieving the 4 per 1000 target}

The analysis was performed for the reference or business-asusual scenario, i.e., the current situation without any change in the area occupied by the cropping systems or in farming practices. The most negative rates of change in SOC level $(-14$ to $-12 \%$ year $^{-1}$; see Fig. 2) were observed for cropping systems based on vegetable crops cultivated in monoculture on 


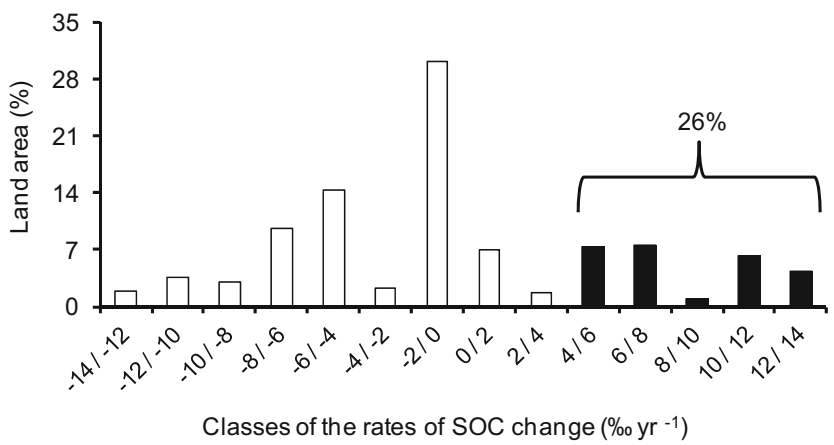

Fig. 2 Land area distribution of annual rates of soil organic carbon (SOC) change observed for the reference scenario at territory scale. The rates are expressed as classes of SOC change from $-14 /-12 \%$ o year ${ }^{-1}$ to $+12 /+$ $14 \%$ year $^{-1}$. Black bars represent the area with SOC change $\geq 4 \%$ o year ${ }^{-1}$ ( $26 \%$ of the total area)

non-amended soils with SOC content $>3.5 \%$. The most positive rates ( 12 to $14 \%$ year $^{-1}$ ) corresponded to amended banana systems cultivated on soils with the lowest SOC content tested in this study (1.5\%; Table A6). Systems with rates $>4 \%$ year $^{-1}$ represented $26 \%$ of total cropland (5627 ha), which corresponded to the 4 per 1000 land area in the reference scenario. The highest frequency $(30 \%)$ was observed for rates ranging between 0 and $-2 \%$ year ${ }^{-1}$, which indicates that a high proportion of cropping systems in Guadeloupe are not far from equilibrium. Most of these situations corresponded to perennial crops cultivated in soils with SOC content $\leq 2.5 \%$.

In absolute terms, AER 1 and AER 2 together contributed two-thirds of the 4 per 1000 land area, or 3702 ha (Fig. 3a). However, in relative terms (i.e., in relation of the land area of each AER), the contribution was highest for AER 4 and AER 5. For example, the 4 per 1000 target was attained on about $60 \%$ of land area in AER 4 and AER 5, but on only $16 \%$ of land area in AER 1. In both absolute and relative terms, the contribution of soils with the lowest SOC content was much higher than that of soils with SOC content $\geq$ $2.5 \%$ (Fig. 3b). Similarly, the contribution of perennial crops to the 4 per 1000 land area was much higher than that of annual crops, in both absolute and relative terms (Fig. $3 c)$. Banana and orchard were found to be the main perennial systems contributing to the 4 per 1000 land area in relative terms. Cropping systems involving annual crops contributed to the 4 per 1000 land area mainly in situations with high rates of organic amendment $(\geq 10 \mathrm{Mg}$ compost $\mathrm{ha}^{-1}$ year $^{-1}$ ) to soils with the lowest SOC content (data not shown).

Despite visual differences between AERs (Fig. 3a), ANOVA results indicated that the effect of AER on the 4 per 1000 land area was not significant (Table 1). This was associated with the fact that differences between AERs were only noticeable for the lowest SOC content and for perennial cropping systems. On the other hand, the effects
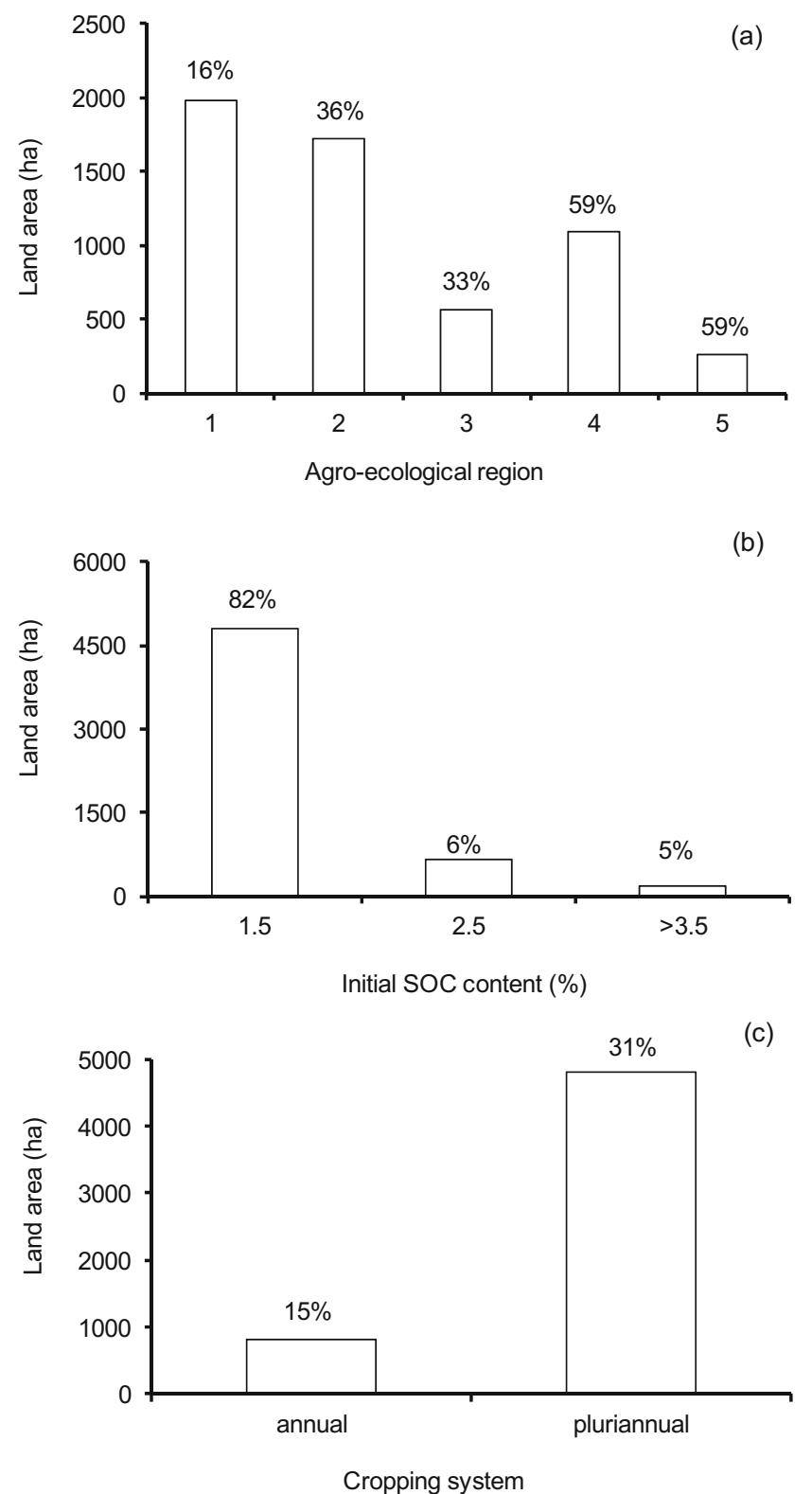

Fig. 3 Impact of a agro-ecological region (AER), b initial soil organic carbon (SOC) content, and c cropping system on the land area on which meeting the 4 per 1000 target is feasible in the reference scenario. Numbers above bars indicate the fraction of 4 per 1000 land area occupied by each specific situation. Values of SOC content in $\mathbf{b}$ represent the middle value of each SOC class presented in Table A6. As the area in 4 per 1000 was nil for SOC contents $\geq 4.5 \%$, we pooled these values of SOC in a single class $>3.5 \%$

of initial SOC content and cropping system were significant and were observed in all scenarios analyzed. Moreover, the impact of cropping system on the 4 per 1000 land area was lower than that of the initial SOC content (Table 1). ANOVA also indicated a significant interaction between cropping system $\times$ initial SOC content (Table 1), which reflected the greater impact of perennial systems at low than at high SOC content (data not shown). 
Table 1 Analysis of variance of the effect of agro-ecological region (AER), initial soil organic carbon (SOC) content, and cropping system (CS) on the land area where the 4 per 1000 target was achieved in the reference scenario. DOF stands for degree of freedom

\begin{tabular}{llrc}
\hline Source of variation & DOF & \multicolumn{1}{c}{$F$} & Level of significance \\
\hline Agro-ecological region (AER) & 4 & 2.0 & 0.19 \\
Initial SOC content (Ci) & 2 & 18.1 & $<0.01$ \\
Cropping system $(\mathrm{CS})^{\mathrm{a}}$ & 1 & 11.6 & $<0.01$ \\
$\mathrm{AER} \times \mathrm{Ci}$ & 8 & 2.1 & 0.17 \\
$\mathrm{AER} \times \mathrm{CS}$ & 4 & 1.0 & 0.47 \\
$\mathrm{CS} \times \mathrm{Ci}$ & 2 & 8.6 & 0.01 \\
Error & 8 & & \\
\hline
\end{tabular}

${ }^{a}$ Annual vs. perennial cropping systems

\section{Effect of changes in land use and farming practices on the $\mathbf{4}$ per $\mathbf{1 0 0 0}$ land area at territory scale}

In this section, we present data on the impact of the scenarios tested on SOC stocks, which we used to analyze the 4 per 1000 land area in a context of SOC changes at territory scale.

The results showed that scenarios including reduced tillage, an increase in the area receiving organic amendments, and the current distribution of cropping systems resulted in higher 4 per 1000 land area than those involving current tillage and organic amendment practices and an increase in the area of crops grown for the local market (Table 2). ANOVA indicated that the impact of changes in cropping systems on the 4 per 1000 land area decreased in the order: tillage management $>$ land use $>$ amended area (Table 3). On average, the 4 per 1000 land area was $24 \%$ under conventional tillage and $30 \%$ under reduced tillage. This increase under reduced tillage was mainly

Table 2 Land area where the 4 per 1000 target was achieved and annual soil organic carbon (SOC) change at territory scale for the eight scenarios tested, which assumed different changes in land use and farming practices. " $+50 \%$ annual crops" indicates a $50 \%$ increase in the area of annual noticeable for soils with initial SOC content of $2.5 \%$ and for cropping systems involving annual crops in monoculture or in rotation with sugarcane (data not shown). ANOVA indicated that the land use $\times$ tillage interaction was significant (Table 3 ), which was due to the fact that differences in land use were lower under reduced than under conventional tillage (Table 2).

Despite the increase in 4 per 1000 land area, the annual SOC change at territory scale was negative (i.e., net SOC losses) for all scenarios, but with great variation between scenarios (Table 2). For example, the ratio between the extreme estimated values of SOC change was 23 ($4426 \mathrm{Mg} \mathrm{C}$ year $^{-1}$ to $-191 \mathrm{Mg} \mathrm{C}$ year $^{-1}$ ). The impact of changes in the cropping systems on SOC losses displayed the same trend observed for 4 per 1000 land area, i.e., tillage management $>$ land use $>$ amended area (Table 3). However, these changes had an overall higher effect on SOC losses than on 4 per 1000 area. For example, reduced tillage increased the 4 per 1000 land area by on average $25 \%$ (variation from $24 \%$ for conventional tillage to $30 \%$ for reduced tillage) and decreased SOC losses by $77 \%$ ( $-2892 \mathrm{Mg} \mathrm{C}$ year $^{-1}$ for conventional tillage compared with $-677 \mathrm{Mg} \mathrm{C}$ year $^{-1}$ for reduced tillage). Increasing the land area devoted to crops for the local market decreased the 4 per 1000 land area by $16 \%$ (variation from $29 \%$ for the current situation to $25 \%$ for a $50 \%$ increase in the area of annual crops) and increased SOC losses by $54 \%$ (from $-1131 \mathrm{Mg} \mathrm{C}$ year $^{-1}$ to $-2438 \mathrm{Mg} \mathrm{C}$ year $^{-1}$ ) (Table 2). The effect of increasing the area receiving organic amendments was significant in terms of 4 per 1000 area (increase of $8 \%$, from 26 to 28\%) and SOC losses (decrease of 34\%, from $2154 \mathrm{Mg} \mathrm{C}$ year $^{-1}$ to $-1415 \mathrm{Mg} \mathrm{C}$ year $^{-1}$ ), but its impacts were lower than those of changes in tillage management and in land use (Tables 2 and 3).

crops grown for the local market. For the area receiving organic amendments (amended area), " $+50 \%$ " corresponds to a $50 \%$ increase in the current amended area

\begin{tabular}{|c|c|c|c|c|c|c|}
\hline \multicolumn{3}{|l|}{ Scenario } & \multirow{2}{*}{$\begin{array}{l}\text { Land area in } 4 \text { per } 1000 \\
\%\end{array}$} & \multicolumn{3}{|c|}{ Annual SOC change at the territory level } \\
\hline Tillage & Land use & Amended area & & $\mathrm{kg} \mathrm{C} \mathrm{ha}^{-1}$ year $^{-1}$ & Mg C year $^{-1}$ & $\%$ year ${ }^{-1 \mathrm{a}}$ \\
\hline \multirow[t]{4}{*}{ Conventional } & Current & Current & $26^{\mathrm{b}}$ & -96 & $-2043^{\mathrm{b}}$ & $-1.5^{\mathrm{b}}$ \\
\hline & & $+50 \%$ & 28 & -69 & -1467 & -1.1 \\
\hline & $+50 \%$ of annual crops & Current & 20 & -208 & -4426 & -3.2 \\
\hline & & $+50 \%$ & 22 & -171 & -3635 & -2.7 \\
\hline \multirow[t]{4}{*}{ Reduced } & Current & Current & 29 & -39 & -824 & -0.6 \\
\hline & & $50 \%$ & 31 & -9 & -191 & -0.1 \\
\hline & $+50 \%$ of annual crops & Current & 28 & -62 & -1325 & -1.0 \\
\hline & & $+50 \%$ & 31 & -17 & -367 & -0.3 \\
\hline
\end{tabular}

a \%o of the initial soil organic carbon (SOC stock)

${ }^{\mathrm{b}}$ Reference scenario 
Table 3 Analysis of variance of the effect of changes in land use and farming practices on soil organic carbon (SOC) in the eight scenarios on the land area where the 4 per 1000 target was achieved at territory scale

\begin{tabular}{|c|c|c|c|c|c|}
\hline \multirow[t]{2}{*}{ Source of variation } & \multirow[t]{2}{*}{ DOF } & \multicolumn{2}{|c|}{ Land area in 4 per 1000} & \multicolumn{2}{|c|}{ Annual SOC change } \\
\hline & & $F$ & Level of significance & $F$ & Level of significance \\
\hline Tillage (TIL) & 1 & 24118 & $<0.01$ & 6448 & $<0.01$ \\
\hline Land use (LU) & 1 & 9213 & 0.01 & 2244 & 0.01 \\
\hline Amended area (AA) & 1 & 3676 & 0.01 & 718 & 0.02 \\
\hline $\mathrm{TIL} \times \mathrm{LU}$ & 1 & 5920 & 0.01 & 1232 & 0.02 \\
\hline $\mathrm{TIL} \times \mathrm{AA}$ & 1 & 7 & 0.23 & 4 & 0.29 \\
\hline $\mathrm{LU} \times \mathrm{AA}$ & 1 & 28 & 0.12 & 24 & 0.13 \\
\hline Error & 1 & & & & \\
\hline
\end{tabular}

\section{Discussion}

The two main findings in this study were that (i) the estimated land area where the 4 per 1000 target can be achieved is relatively important, despite the fact that the tropical territory studied here involved soils characterized by high SOC stocks and high SOC mineralization rates, which makes any additional increase in SOC stocks difficult; and (ii) the changes in SOC stocks at territory scale were negative under all scenarios tested and the impact of the changes in farming practices was more important in reducing SOC losses than in increasing the area where 4 per 1000 is achievable. These results are discussed separately in the following sections.

\section{Impact of initial soil organic carbon stocks and cropping system on 4 per 1000 land area}

Among the factors analyzed for their effects on 4 per 1000 land area in this study, initial soil organic carbon stocks and cropping system (annual vs. perennial) were the most important. The impact of the initial SOC stocks has been reported previously in studies in temperate and tropical regions. For example, in a modeling study carried out in France, Pellerin et al. (2019) reported that the adoption of good farming practices could achieve additional SOC storage of $1.9 \%$ o considering all forest and agricultural soils, 3.3\%o considering only agricultural soils, and $5.2 \%$ considering only agricultural soils under cereals and oilseed crops. Pellerin et al. (2019) attributed these differences to the different initial SOC stocks in forest (higher) and agricultural soils (lower), with the lowest stocks observed for soils under cereal crops. Similar results on the impact of initial SOC stocks on the 4 per 1000 target have been reported by Minasny et al. (2017) for 20 temperate and tropical regions of the world; by Corbeels et al. (2019) for agricultural systems in sub-Saharan Africa; and by Wiesmeier et al. (2020) for agricultural soils (cropland and grassland) in Bavaria. As pointed out by Lal (2010), the higher potential of agricultural soils to increase SOC stocks compared with other lands uses is likely to relate to SOC depletion, since conversion from natural to agricultural ecosystems, mainly in tropical regions, generally results in a significant loss of SOC. Moreover, from a mathematical point of view, the impact of initial SOC stocks on 4 per 1000 land area is associated with the fact that the baseline is expressed in relative terms of SOC increase. In absolute terms, the amount of C necessary to attain 4 per 1000 is smaller in soils with low SOC stocks (Chenu et al. 2019). For example, in soils of AER 2 under sugarcane monoculture in our study, annual $\mathrm{C}$ inputs to reach 4 per 1000 were about $40 \%$ higher in soils with $2.5 \%$ initial SOC content (equivalent to $66 \mathrm{Mg} \mathrm{Cha}^{-1}$ ) than in soils with $1.5 \%$ initial SOC content (equivalent to $39 \mathrm{Mg} \mathrm{C}^{-1}$ ), which required annual $\mathrm{C}$ inputs of $2.8 \mathrm{Mg} \mathrm{C} \mathrm{ha}^{-1}$ year $^{-1}$ and $1.7 \mathrm{Mg} \mathrm{ha}^{-1}$ year $^{-1}$, respectively.

Most cropping systems based on perennial crops showed positive rates of SOC change, indicating $\mathrm{C}$ sequestration, while most systems including annual crops presented negative values, indicating $C$ losses. Thus, the 4 per 1000 area was much higher for perennial systems in absolute and in relative terms (Fig. 3c). Differences between cropping systems were due to two factors: (i) annual systems based on vegetables and tuber crops are characterized by a smaller mass of crop residue recycling in soil compared with perennial crops such as sugarcane and banana (i.e., smaller C input) (Luo et al. 2010; Sierra et al. 2015), and (ii) soil tillage intensity is higher for annual crops, which enhances $\mathrm{C}$ losses (Bhattacharyya et al. 2007; Sierra et al. 2017). In a study dealing with SOC storage in agroforestry systems in sub-Saharan Africa, Corbeels et al. (2019) also observed a strong impact of cropping system on the 4 per 1000 area, which was higher for multi-strata agroforestry than for alley cropping systems with annual crops.

The effect of AER on 4 per 1000 area was not significant in our study, probably due to the fact that this effect was masked by those of the cropping systems and initial SOC stocks. In practice, cropping systems are not evenly distributed on the territory of Guadeloupe, but are concentrated in specific AERs, with e.g., sugarcane and tuber crops dominating in AER 1 and AER 2, and banana and vegetable crops in AER 3 and AER 4. Opposing effects of perennial and annual crops 
could negate any impact of AER on 4 per 1000 land area at territory scale. Similarly, AER 4 and AER 5 soils had lower SOC stocks (see "Study site and agro-ecological characteristics" section), which explains why the 4 per 1000 land area was higher in these regions in relative terms (Fig. 3a).

Our results suggest that, although 4 per 1000 land area is relatively important, achieving a further increase can be difficult in the initial situation on Guadeloupe, because the remaining land area of soils with low SOC stocks is small (Fig. 3a). Thus, any increase in the 4 per 1000 land area will have to involve more fertile soils, which raises the constraint discussed above concerning the effect of high initial SOC stocks. Moreover, the initial regional shift in agricultural production towards domestic markets is increasing the land area occupied by annual crops, which have a negative effect on the 4 per 1000 land area, as discussed in the following section.

\section{Role of land use and farming practices in reaching the 4 per 1000 target at territory scale}

Scenarios involving a decrease in $\mathrm{C}$ losses (e.g., reduced tillage) or an increase in $\mathrm{C}$ inputs (e.g., increase in the area receiving organic amendments) showed an increase in 4 per 1000 land area in relation to the reference scenario. The opposite was observed for scenarios involving expansion of the current land area occupied by annual crops. Although these results agree with existing knowledge on SOC dynamics (e.g., Powlson et al. 2016), they also indicate that the 4 per 1000 level is mainly controlled by $\mathrm{C}$ losses, which disagrees with findings concerning the major role played by $\mathrm{C}$ inputs (Virto et al. 2012; Castellano et al. 2015; Autret et al. 2016). This discrepancy can be attributed to two factors. First, the tropical soils on Guadeloupe are characterized by high levels of SOC mineralization and high SOC content, which together enhance SOC losses. The SOC content in our study was at least 50\% higher than that observed in the temperate soils in France studied by Autret et al. (2016). The reduction in C losses via reduced soil tillage on our tropical soils will then obviously be greater than in temperate soils with lower mineralization rates and SOC contents. Second, high importance of $\mathrm{C}$ inputs is generally reported in studies examining the effect of cover crops (e.g., Virto et al. 2012) or comparing crop residue management (removal vs. no removal). These conditions are irrelevant for Guadeloupe, because crop residues are kept as mulch or incorporated into the soil, and cover crops are not used in the main cropping systems. Based on a review of the factors affecting soil $\mathrm{C}$ sequestration, Chenu et al. (2019) concluded that a given additional $\mathrm{C}$ input leads to higher additional SOC stocks in temperate soils than in tropical soils, due to lower SOC turnover under temperate conditions. Some studies have found that the potential of no-till and reduced tillage to store SOC is limited (e.g., Powlson et al. 2014), but the high impact of reduced tillage found in the present study agrees with experimental data obtained in Guadeloupe by Sierra et al. (2017). They observed that reducing soil tillage strongly decreased SOC losses in vegetables and tuber crop systems, and induced a slight increase in SOC stocks (3\% in 15 years, which is equivalent to $2 \%$ year $^{-1}$ ) (Sierra et al. 2017). Based on these findings, we suggest that the priority should be to reduce SOC losses from SOC-rich soils with adapted practices such as reduced tillage primarily

Increasing the area receiving organic amendment area was relatively less important in our study, because the average rate of organic matter addition is low in most cropping systems in the study area (Table A2). At territory scale, the total amount of organic amendments (as fresh matter) applied was 24 $000 \mathrm{Mg}$ year $^{-1}$ in the reference scenario and 36 $000 \mathrm{Mg}$ year $^{-1}$ in scenarios involving an increase in the areas receiving amendments. These values correspond to average rates of $1.1 \mathrm{Mg}$ fresh matter $\mathrm{ha}^{-1}$ year $^{-1}$ and $1.7 \mathrm{Mg}$ fresh matter ha ${ }^{-1}$ year $^{-1}$, respectively, which are too small to induce SOC sequestration at 4 per 1000 level over a great land area at territory scale. A recent study carried out in Guadeloupe indicated that the current availability of organic amendments is around $26000 \mathrm{Mg}$ fresh matter year ${ }^{-1}$, which could increase to $40000 \mathrm{Mg}$ fresh matter year ${ }^{-1}$ with better management of organic wastes derived from agro-industrial factories and water treatment plants (Paul et al. 2017). However, these numbers show that a further increase in 4 per 1000 land area by promoting use of organic amendments is rather unrealistic. Similar results have been reported by Mondini et al. (2018) in a modeling study examining the impact of use of composts in tackling GHG emissions in Italy. They estimated that soil C sequestration from all Italian compost production corresponded to only $5.3 \%$ of total annual GHG emissions, and concluded that composts should be used on soils with the greatest potential for $\mathrm{C}$ sequestration in order to improve their fertility, not to offset GHG emissions (Mondini et al. 2018).

As a large proportion of annual rates of SOC change were near the equilibrium value (Fig. 2), positive effects of farming practices on SOC stocks induced a strong decrease in SOC losses and caused $\mathrm{C}$ sequestration in some situations. Strictly speaking, there is no SOC equilibrium state in the context of a continuously changing climate. However, the simultaneous impact of warming in increasing SOC mineralization and the amount of crop residues in some cropping systems may induce a quasi-equilibrium in SOC, because of the partial offset between C outputs and inputs (Chopin and Sierra 2019). In the present study, this was the case for several vegetable cropping systems based on $\mathrm{C} 3$ plants when reduced tillage was applied to soils with low SOC content, with annual rates of SOC change close to $0 \%$. The positive effects of the change in farming practices were smaller for 4 per 1000 land area, because these impacts were mainly obtained in the range $0-4 \%$ o year $^{-1}$. Thus, the positive impacts were not large enough to attain the baseline of 4 per 1000 in most cropping systems. 
These findings question the effectiveness of promoting changes in farming practices at farm scale, mainly in the context of a shift in agricultural production toward the domestic market. Our study showed that SOC losses were largest in this scenario and that adoption of good farming practices could reduce them significantly (Table 2). We argue that in the study area, the change in practices may be beneficial for soil quality and adaptation of agriculture to climate change, but its role in increasing the 4 per 1000 land area would be limited.

\section{Conclusions}

Using the Guadeloupe archipelago as the case study provided a large range of soils, climates, crops, and farming practices, which allowed the major factors affecting the 4 per 1000 target under the tropical conditions of the Caribbean to be assessed. Our results indicated that reduced $\mathrm{C}$ losses is the main lever for increasing $\mathrm{C}$ sequestration or at least maintaining current SOC stocks. A second lever could be increased use of organic amendments, but the impact of this farming practice depends strongly on local availability of amendments of suitable quality. Overall, the 4 per 1000 target would be mainly achievable to a limited extent in SOC-poor soils under perennial systems. In fact, the 4 per 1000 area in the best scenario tested in this study was only around one-third of total cropland and was accompanied by a net SOC loss at territory scale. The relatively high SOC stocks in the volcanic and calcareous soils of the Caribbean region and the negative effect of annual crops on the SOC balance are major constraints to successful application of the "4 per 1000 Initiative" in the Caribbean. This raises the question of a potential negative impact of the current shift in Caribbean agriculture towards cropping systems based on annual crops. However, our analysis was limited to wellaccepted farming practices and did not include other practices such as agroforestry and mixed crop-livestock systems, which can promote $\mathrm{C}$ sequestration to a major extent. Nevertheless, implementation of new cropping systems would require economic incentives to ensure uptake by farmers. We suggest that limiting $\mathrm{C}$ losses should be the priority, in order to maintain the overall services delivered by soils, such as nutrient cycling, water retention, and improved physical structure for sustaining agricultural production, particularly in a climate change context.

Supplementary Information The online version contains supplementary material available at https://doi.org/10.1007/s10113-020-01740-4.

Acknowledgments We would like to thank Mary McAfee from ScanText for reviewing the English manuscript.

Funding Open Access funding provided by Swedish University of Agricultural Sciences. This study formed part of the TropEmis Project funded by the Reacctif Program of the French Environment and Energy
Management Agency (ADEME) (grant 410-00159), the European Regional Development Fund (FEDER) (grant 410-00160), and the Regional Council of Guadeloupe (grant 410-00161). The first author received funding from the Cropping System Platform from the Swedish University of Agricultural Sciences (SLU).

Open Access This article is licensed under a Creative Commons Attribution 4.0 International License, which permits use, sharing, adaptation, distribution and reproduction in any medium or format, as long as you give appropriate credit to the original author(s) and the source, provide a link to the Creative Commons licence, and indicate if changes were made. The images or other third party material in this article are included in the article's Creative Commons licence, unless indicated otherwise in a credit line to the material. If material is not included in the article's Creative Commons licence and your intended use is not permitted by statutory regulation or exceeds the permitted use, you will need to obtain permission directly from the copyright holder. To view a copy of this licence, visit http://creativecommons.org/licenses/by/4.0/.

\section{References}

4 per 1000 Initiative (2020) The 4p1000 initiative. Available at: https:// www.4p1000.org. Accessed 17.06.20

Akpa SIC, Odeh IOA, Bishop TFA, Hartemink AE, Amapu IY (2016) Total soil organic carbon and carbon sequestration potential in Nigeria. Geoderma 271:202-215. https://doi.org/10.1016/j. geoderma.2016.02.021

Autret B, Mary B, Chenu C, Balabane M, Girardin C et al (2016) Alternative arable cropping systems: a key to increase soil organic carbon storage? Results from a 16 year field experiment. Agric Ecosyst Environ 232:150-164. https://doi.org/10.1016/j.agee.2016. 07.008

Bhattacharyya T, Pal DK, Easter M, Batjes NH, Milne E et al (2007) Modelled soil organic carbon stocks and changes in the IndoGangetic Plains, India from 1980 to 2030. Agric Ecosyst Environ 122:84-94. https://doi.org/10.1016/j.agee.2007.01.010

Brisson N, Levrault F (2011) Green Book of the CLIMATOR Project: climate change, agriculture and forests in France: simulations of the impacts on the main species. ADEME, Paris

Castellano MJ, Mueller KE, Olk DC, Sawyer JE, Six J (2015) Integrating plant litter quality, soil organic matter stabilization, and the carbon saturation concept. Glob Chang Biol 21:3200-3209. https://doi.org/ 10.1111/gcb.12982

Chenu C, Angers DA, Barre P, Derrien D, Arrouays D et al (2019) Increasing organic stocks in agricultural soils: knowledge gaps and potential innovations. Soil Tillage Res 188:41-52. https://doi.org/ 10.1016/j.still.2018.04.011

Chopin P, Sierra J (2019) Reduced tillage and organic amendments can offset the negative impact of climate change on soil carbon: a regional modelling study in the Caribbean. Soil Tillage Res 192:113120. https://doi.org/10.1016/j.still.2019.05.009

Colmet-Daage F, Lagache P (1965) Caractéristiques de quelques groupes de sols dérivés de roches volcaniques aux Antilles françaises. In: Cahiers ORSTOM Série Pédologie 3, pp 91-121

Corbeels M, Cardinael R, Naudin K, Guibert H, Torquebiau E (2019) The 4 per 1000 goal and soil carbon storage under agroforestry and conservation agriculture systems in sub-Saharan Africa. Soil Tillage Res 188:16-26. https://doi.org/10.1016/j.still.2018.02.015

Eggleston S, Buendia L, Miwa K, Ngara T, Tanabe K (2006) 2006 IPCC guidelines for national greenhouse gas inventories. Institute for Global Environmental Strategies Hayama, Japan

Lal R (2010) Managing soils and ecosystems for mitigating anthropogenic carbon emissions and advancing global food security. BioScience 60:708-721. https://doi.org/10.1525/bio.2010.60.9.8 
Lal R (2019) Promoting "4 Per Thousand" and "Adapting African Agriculture" by south-south cooperation: conservation agriculture and sustainable intensification. Soil Tillage Res 188:27-34. https:// doi.org/10.1016/j.still.2017.12.015

Lal R (2020) Food security impacts of the "4 per Thousand" initiative. Geoderma 374:114427. https://doi.org/10.1016/j.geoderma.2020. 114427

Luo Z, Wang E, Sun OJ (2010) Can no-tillage stimulate carbon sequestration in agricultural soils? A meta-analysis of paired experiments. Agric Ecosyst Environ 139:224-231. https://doi.org/10.1016/j.agee. 2010.08.006

Milne E, Apotsos A, Betemariam E, Bationo A, Batjes N et al (2016) Grazing lands in Sub-Saharan Africa and their potential role in climate change mitigation: what we do and don't know. Environ Dev 19:70-74. https://doi.org/10.1016/j.envdev.2016.06.001

Minasny B, Malone BP, McBratney AB, Angers DA, Arrouays D et al (2017) Soil carbon 4 per mille. Geoderma 292:59-86 . https://doi. org/10.1016/j.geoderma.2017.01.002

Minasny B, Arrouays D, Mcbratney A, Angers D, Chambers A et al (2017) Rejoinder to Comments on Minasny et al., 2017 Soil carbon 4 per mille Geoderma 292, 59-86. Geoderma 309. https://doi.org/ 10.1016/j.geoderma.2017.05.026

Mondini C, Cayuela ML, Sinicco T, Fornasier F, Galvez A et al (2018) Soil C storage potential of exogenous organic matter at regional level (Italy) under climate change simulated by RothC model modified for amended soils. Front Environ Sci 6:144. https://doi.org/10. 3389/fenvs.2018.00144

Paul J, Sierra J, Causeret F, Guindé L, Blazy J-M (2017) Factors affecting the adoption of compost use by farmers in small tropical Caribbean islands. J Clean Prod 4:1387-1396. https://doi.org/10.1016/j. jclepro.2016.11.168

Pellerin S, Bamière L, Launay C, Martin R, Angers D et al (2019) Stocker du carbone dans les sols français, Quel potentiel au regard de l'objectif de 4 pour 1000 et à quel coût ? Synthèse du rapport d'étude, INRA, France

Powlson DS, Stirling CM, Jat ML, Gerard BG, Palm CA et al (2014) Limited potential of no-till agriculture for climate change mitigation. Nat Clim Chang 4:678-683. https://doi.org/10.1038/nclimate2292

Powlson DS, Stirling CM, Thierfelder C, White RP, Jat ML (2016) Does conservation agriculture deliver climate change mitigation through soil carbon sequestration in tropical agro-ecosystems? Agric Ecosyst Environ 220:164-174. https://doi.org/10.1016/j.agee.2016. 01.005

Rumpel C, Amiraslani F, Chenu C, Garcia Cardenas M, Kaonga M et al (2020) The 4p1000 initiative: opportunities, limitations and challenges for implementing soil organic carbon sequestration as a sustainable development strategy. Ambio 49:350-360. https://doi.org/ 10.1007/s13280-019-01165-2

Saint Ville AS, Hickey GM, Phillip LE (2015) Addressing food and nutrition insecurity in the Caribbean through domestic smallholder farming system innovation. Reg Environ Chang 15:1325-1339. https://doi.org/10.1007/s10113-015-0770-9

Sierra J, Causeret F, Diman JL, Publicol M, Desfontaines L et al (2015) Observed and predicted changes in soil carbon stocks under export and diversified agriculture in the Caribbean. The case study of Guadeloupe. Agric Ecosyst Environ 213:252-264. https://doi.org/ 10.1016/j.agee.2015.08.015

Sierra J, Causeret F, Chopin P (2017) A framework coupling farm typology and biophysical modelling to assess the impact of vegetable crop-based systems on soil carbon stocks. Application in the Caribbean. Agric Syst 153:172-180. https://doi.org/10.1016/j. agsy.2017.02.004

Soussana J-F, Lutfalla S, Ehrhardt F, Rosenstock T, Lamanna C et al (2019) Matching policy and science: rationale for the ' 4 per 1000 soils for food security and climate' initiative. Soil Tillage Res 188 : 3-15. https://doi.org/10.1016/j.still.2017.12.002

Virto I, Barré P, Burlot A, Chenu C (2012) Carbon input differences as the main factor explaining the variability in soil organic $\mathrm{C}$ storage in no-tilled compared to inversion tilled agrosystems. Biogeochemistry 108:17-26. https://doi.org/10.1007/s10533-011-9600-4

Wiesmeier M, Mayer S, Burmeister J, Hübner R, Kögel-Knabner I (2020) Feasibility of the 4 per 1000 initiative in Bavaria: a reality check of agricultural soil management and carbon sequestration scenarios. Geoderma 369:114333. https://doi.org/10.1016/j.geoderma.2020. 114333

Publisher's note Springer Nature remains neutral with regard to jurisdictional claims in published maps and institutional affiliations. 